\title{
Solidarity, diversity and the quality of government
}

\author{
Bo Rothstein \\ Blavatnik School of Government \\ And \\ Nuffield College \\ University of Oxford \\ Bo.Rothstein@bsg.ox.ac.uk
}

[Forthcoming in The Strains of Commitment: The Political Sources of Solidarity in Diverse Societies, edited by Keith Banting and Will Kymlicka. Oxford University Press] 


\section{Points of departure}

Looking out over the world, both the rich industrial nations as well as the less developed countries, it is striking how large differences there are in social, economic and political equality. Measures of political and legal rights, which can be understood as expressions of democratic or political solidarity, vary enormously also between countries that have about the same level of prosperity (Bohara et al. 2008; Donnelly 2003). The same goes for measures of economic inequality as well as most measures of human well-being such as poverty, literacy, and population health that all can be seen as aspects of redistributive or social solidarity. Social solidarity, understood as the sum of political practices that increases equality in people's overall life chances, (that is, the welfare state broadly understood) is also something that varies a lot also between otherwise quite similar countries (Radcliff 2013). This raises a simple yet important question: What makes some societies more prone to political and broad based social solidarity than others?

The starting point for this article is based on the results from several empirical studies showing that for a vast majority of people, human well-being would be improved if political and social inequality would decrease in their society (Radcliff 2013; Wilkinson and Pickett 2009; cf. Hall and Lamont 2009). The first question that then needs to be answered is how the necessary amount (and type) of solidarity that is needed to produce the policies that will enhance social and economic equality can be politically manufactured. The second question concerns the relation 
between various forms of diversity and the possibility to generate broad based social and political solidarity (Banting 2010). Based on the notion that there is a causal link between the level of generalized social trust in a society and its propensity for social solidarity (Rothstein and Uslaner 2005), the problem is that a large number of studies have shown that increased diversity has a negative effect on social trust (Schaeffer 2013, 2014). As argued by Putnam $(2007,138)$, "immigration and ethnic diversity challenge social solidarity and inhibit social capital".

A second point of departure is that the level of solidarity in a country is not culturally determined. For example, the Nordic countries are not more egalitarian and less corrupt than Italy, the UK, Kenya, Brazil, Hungary or the US because there is something special with the Nordic culture. This is an often heard argument, for example, John Roemer argues that the reason the Nordic countries developed more extensive system of redistribution is due to the educational and cultural homogeneity of their population (Roemer 2009). The problem is that his argument is empirically unsubstantiated and from what is known from the historical research about history of class structure in the Nordic countries, inaccurate. For example, Finland had very low levels of education well into the first decades of the $20^{\text {th }}$ century and a severe conflict between the Finnish and Swedish speaking population (Uslaner and Rothstein 2012). Moreover, the country endured a gruesome civil war in 1918 in which, as a percentage of the population, more people were killed than in the Spanish Civil War during the 1930s. The high levels of cooperation and solidarity in the Nordic countries is thus not culturally or historically predetermined. The broad based political support for the welfare state has instead been politically constructed "from above" by the universal (or near universal) design of the policies (Rothstein 
1998; Alestalo, Hort, and Kuhnle 2009, cf. Anttonen, Häikiö, and Kolbeinn 2012). The same institutionally driven broad based support for universal type of social policies can be found in the UK for the National Health Service (Klein 2010) and in the United States for Social Security (Béland 2005). In fact, the International Social Survey carried out in 2009 shows that support for the idea that "the government should spend (much) more on old age pensions' is higher in the United States than in the Nordic countries (64 per cent compared to 58.5 per cent, Bechert and Quandt 2009, see also Kenworthy 2014, 150-55). I agree with Kenworthy's argument that "the difference between Nordic and American policies is one of degree, not of kind" $(2014,121)$. One can also argue that the success of the "bolsa familia" conditional cash transfer programs in many Latin American countries indicates that it is the design "from above" of social policies that explain solidarity, not the other way around (Rawlings and Rubio 2005; Sugiyama and Hunter 2013). The recent introduction of more universal type of social policy reforms in several Latin American countries in areas such a health care, pensions and education shows the existence of the same causal logic as in the Nordic countries (Pribble 2013) It thus seems that it is the institutional design of the policies and not the specific national culture or history that determines if country will have social policies that can be seen as expressions of broad based social solidarity. In political terms, as stated by Tsebelis (1990), designing institutions is the sophisticated equivalent to designing policies. A first conclusion is that if increased social solidarity is the goal, thinking about how to design the institutions that implement social policies turns out to be of the outmost importance. 


\section{Constructive political theory}

Empirical research and normative theory seldom meet. Not least political science is a highly compartmentalized discipline with surprisingly little communication, not to say collaboration, between its various specializations. This is lack of intra-disciplinary communication between political philosophy and empirical research severely limits the capability to provide useful knowledge (Dryzek, Honig, and Phillips 2006). To manufacture a sustainable solidaristic society, we need knowledge from political philosophy for understanding what social solidarity ought to be about. From empirical research we need knowledge about at least three things. First, what type of public programs can governments implement without creating administrative nightmares that are likely to delegitimize the policies in the eyes of the majority of the electorate? Secondly, we need to know what type of public policies for increased social solidarity that can generate broad-based and sustainable electoral support. Lastly, we also need knowledge about what can motivate or turn people away from supporting policies for social solidarity. Following Lundquist, I call this effort to combine insights from political philosophy and empirical research about the possibilities for getting electoral support and being able to implement social policies for “constructive theory" (Lundquist 1988).

Although analyses in political philosophy about social justice can be utterly sophisticated and complex, the basic ambition is to answer a fairly simple question, namely: What ought the state to $d o$ ? Or a little more precisely: What should be the responsibility of the individual and for what can citizens' claim support from the state (Rothstein 1998). The empirical research into the 
possibilities for governments to get support for and also actually implement policies for increased social solidarity can be seen as answering the issue known as "state capacity", or in other words: What can the state do? This can be understood as an ambition to establish an empirical theory of the state while the philosophical enterprise can be seen as a normative state theory. The idea behind establishing a constructive state theory is to analyse where these two intellectual enterprises intersect. Needless to say, there are many things states can but which they, according to the "findings" in political philosophy, should not do. However, the opposite is also true. As I will argue below, there are many policies that one, from various theories of justice, may argue they state ought to do but for which the empirical research comes with a clear result - namely that they can either not be implemented without creating massive administrative problems or it will turn out to be impossible to get the necessary electoral support (see also Wolff 2011). Figure 1 intends to show how empirical, normative and constructive theories of the state are related.

Figure 1 Empirical, normative and constructive state theories 


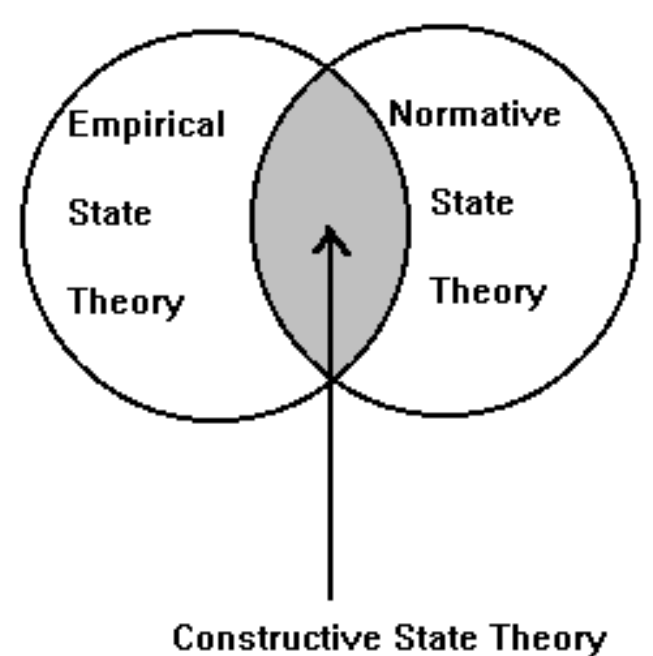

This argument for a constructive theory of the state and politics differs from the argument presented by Raymond Geuss (2008) and other so called "political realists" who argues for a non-ideal political philosophy that is particularistic and historicist. I agree with the critique launched by Erman and Möller (2015) that this type of "political realism" risks throwing out the baby with the bathwater by closing the normative space upon which political legitimacy must rely. In order to determine the "space" for a constructive theory, "ideal theory" of for example liberal egalitarians such as John Rawls and Ronald Dworkin is essential (Erman and Möller 2013). Figure 1 also intends to show that holding on to "ideal theory" in political philosophy does not necessarily imply that "real politics" should be seen as a subordinate arena where moral principles are just to be applied. Instead, the constructive approach implies that the empirically based knowledge about how this arena works and, most importantly, what it can and cannot 
accomplish when it comes to increased social justice, should be given equal weight to the arguments presented in political philosophy.

This constructive approach implies that we do not follow the advice given by Bruce Ackerman, namely that we should start from the the assumption of "a polity possessed of a perfect technology of justice" or that we should assume that we "live in a place where there never is any practical difficulty implementing the substantive conclusions" (Ackerman 1980, 23). Another example comes from Richard Arneson who discusses the problem if welfare distribution should be tailored to people's preferences. First, he recognizes that this would perhaps be impossible because we could not imagine public authorities with the capacity to collect and use the amount of information necessary to accomplish such a task. Nevertheless, he states that he will "ignore these practical feasability problems" and instead "assume that correct and full information regarding people's preferences is available at no cost whatsoever to whatever institutions we establish to implement the principles of distributive justice that we accept" (Arneson 1990, 158f). Although such reasoning may be justified as interesting thought experiments, they are outside the field of what I define as constructive state theory and come with, as I will show below, obvious risks concerning the possibilities to transform normative principles of justice into policies for social solidarity that can be realized. Needless to say, empirical research into this area that is carried out in the absence of a serious reflection of its normative implications is also dangerous and irresponsible since it is likely to end in mindless utilitarianism where the dignity and rights of individuals may be sacrificed for some future overall good. As is well-known, Rawls philosophical project started out from a critique of the utilitarianism he spotted in the 
Third Reich reacting to the idea that the majority for its own utility could exterminate a minority (Nussbaum 2001).

When using political philosophy in this constructivist way, one problem is that many political philosophers are uninterested of and unaware of the political importance of the organizational and institutional sides of politics. When they deal with the question of what the (democratic) state ought to do, they often ignore the problem of what this state is capable of doing. David Estlund even claims that political philosophy is easily distorted by an "ever present thought that it might be of practical importance" $(2008,1)$. Political philosophers have also shown remarkable little interest in research of what type of social policies that can generate enough electoral support to be sustainable.

A central problem is thus that issues about the institutional design or implementation of policies are, with a few exceptions, ignored in modern political philosophy. As Wolff states: philosophers tend to "fall short of taking up the challenge of thinking hard about questions of the process and, even more importantly, consequences of implementation" (Wolff 2011, 192). One example comes from the so called "luck egalitarians" in political theory who argue that citizens should only be compensated for problems in their lives that they themselves cannot be held responsible for. This main idea is that differential impact of circumstances for which an individual cannot reasonably be held responsible ("brute luck") are to be neutralized, by some type of public policy whereas consequences due to the different choices people make (“option luck"), are to be left intact. A typical case is John Roemer's idea that when to decide if people who have attracted 
lung cancer should get medical treatment by a public program, patients should be divided into classes which would give us information about if their decision to smoke was their own responsibility or not. As he argues, the choice to smoke is "determined" by a person's social circumstances such as her class, ethnicity, gender, education, etc. As Roemer argues, a steel worker should get the costs for treating his lung-cancer covered by the state because he is in a social category where say 90 percent smoke so smoking is not a choice he can be seen to be responsible for. However, our solidarity should, according to Roemer, not be extended to a female college professor who gets this disease because in her "class", less than ten percent smoke so smoking is a choice she has made and she has to take the costs for medical treatment herself (Roemer 1996, 1995, 1998). The problem with this approach is that anyone with the slightest knowledge in research about implementation problems in public policy would realize that having a bureaucracy that would a) collect all this information about citizens and b) make decisions based on this mountain of information would create an administrative Leviathan that would severely delegitimize any public health care insurance system (Rothstein and Uslaner 2005). How could the information and integrity problems for solving the problem of personal responsibility for issues like obesity, venereal diseases and injuries from dangerous sport activities be solved? What type of administration could handle the issue if unemployment is due to "brute luck" for which the individual has the right to receive unemployment insurance, or a result of the choices for which the individual should be held responsible, such as not showing enough efforts in getting new skills following the changes in the global economy (Risse 2002). I wish the "luck-egalitarians" best of luck with solving these issues because they will for sure need it. In sum, the policies that would follow from "luck egalitarians" such as Roemer are likely to 
result in implementation nightmares that from what is very well known from empirical research would create a political majority against increased efforts for social justice.

Another similar example is the extended debate about the idea of an unconditional basic income (Birnbaum 2012; Veen and Groot 2000; Van Parijs 1992; Offe 2004). As shown by De

Wisplaere and Stirton (2011), the proponents of this policy have disregarded a number of very difficult implementation issues. One is to decide who has the right to this benefit? Should it be only citizens or also immigrants? Should this include also temporary immigrants (guest workers) and tourists that just have decided to stay in the country? What about citizens that have decided to emigrate or immigrants that have left for another country? Can a payment system that includes the homeless be organized? Moreover, the most likely outcome of such a policy is that many young citizens would start their independent life living on such a basic income. One likely result of this is that in many cases their ambitions to increase their human capital by entering into types of education where they would have to study hard would be thwarted. Instead, after a couple of years living on this meagre benefit, many would try to increase their incomes by working on the "black market" or by other (and worse) forms of illegal behaviour. This would create a political majority that would demand cuts in the basic income level, which in its turn would increase the number of people supplementing their basic income with illegal types of income, and so on. Leading proponents of the basic income idea generally argue that issues about political feasibility are of "little relevance" when they formulate their ideas (Van Parijs 2013, 178). However, from what is known from research about political support for social policies, the basic income idea is in all likelihood a sure recipe for creating an electoral majority against increased 
social solidarity because it fails what I would call "the reciprocity test" (see below and also Svallfors 2012, 2007; Larsen 2008, 2007; Cavala and Wildavsky 1970; Scharpf 2000; Bay and West Pedersen 2006; Kumlin 2004; Solevid 2009). To summarize, much of what is produced by modern political philosophy for increasing social solidarity is at an ethical level that can be compared to if medical researcher would prescribe drugs and treatments without considering any side effects for the people they have set out to cure.

\section{What should social solidarity be about?}

Anyone who is interested in increasing social solidarity for achieving a more equal society needs to be in possession of a correct understanding of "the nature of the problem". To achieve this, one has to answer three questions. The first is the "what is it" question, namely what should social solidarity be about? The second is the "how to get it" question, that is, what can be expected from (the vast majority of) humans when it comes to their propensity for solidarity. The third question is about strategy, namely how to make social solidarity politically (electorally) sustainable in a democracy.

The first question, known as "equality of what?", has turned out to be complicated (Sen 1979). In an era of "conspicuous consumption" and increased individualism and social, heterogeneity, it is difficult to argue that the government has a responsibility to equalize all or even most forms of consumption. First, consumption cannot be an end in itself and secondly, many believe we should reward ambition and maybe also talent. The best answers to the question "equality of 
what" have been given by liberal right-based philosophers such as John Rawls, Amartya Sen and Martha Nussbaum (Rawls 1971; Sen 2010; Nussbaum 2001). They differ in certain important respects, but they agree that equality should be about guaranteeing access to a specific set of goods and services that are important for people in order for them to be capable to realize their various potentials as human beings. The central term for Rawls is "primary goods", and for Sen and Nussbaum "capabilities". The terminology implies that the problem is not to equalize economic resources or social status as such, but to ensure all individuals a set of basic resources that will equalize their chances to reach their full potential as humans. Standards are access to high quality health care and education, basic food and shelter, equality in civil and political rights, equal protection under the laws, basic social services and social insurance systems that support people that for various reasons cannot generate enough resources from their own work, support for persons with disabilities, etc. The set of such capabilities enhancing goods and services can of course vary, but it is important to realize that equality, as a politically viable concept, has to be about specific things. ${ }^{1}$ There is simply no way we, by political means, can equalize the ability to be a skilled musician, to be creative, to be loved, to be an outstanding researcher, a good parent or a first rate ballet dancer. What is possible to do by political means is to increase the possibility for those who happen to have ambitions in these (and many other) fields to realize their talents even if they have not entered this world with the necessary economic endowments to do this. This can be done by giving them access to a certain bundle of goods and services that are likely to enhance their capabilities of reaching their full potential as human beings. 
One problem is that any set of such basic resources that are politically decided will carry a strong notion of collectivism. In a society where cultural differences are small, this may not be a problem. However, for most advanced western societies, survey studies give a clear picture of an increasing individualism which is not only related to diversity but that seems to be a universal phenomenon. However, this increased individualism should not be conflated with increased egoism (Welzel 2010). A detailed analysis of the data from the World Value Study shows that the individualism-collectivism dimension is unrelated to the egoism- civicness dimension. Already in 1992, analysing the Swedish data from the World Value Survey, Pettersson and Geyer concluded the following about the then "new individualists":

Compared with the less individualistically-inclined, moreover, they do not show any stronger interest in increasing today's wage differentials, they do not evidence any greater tendency to view the poor with a "they-just-have-themselves-to-blame" attitude, they do not show any stronger tendency to regard their fellow beings in less of a spirit of trust and fellowship. ... They are neither the irrepressible entrepreneurs imagined by the neo-liberals nor the selfish egoists supposed by the social democrats. (cit. in Rothstein 1998, 198)

Using the 2010 data from the World Value Study, we have been able to replicate this result. ${ }^{2}$ However, one conclusion from this empirical result is that we can think about this valueorientation as "solidaristic individualism" as opposed to "solidaristic collectivism" which implies that policies for increased social solidarity need to take this into account. One implication from this is that equality should be about individuals, not collectives such as classes, groups, clans or 
tribes whether these are based on social class, occupation, kinship, religion, gender, ethnicity, sexual orientations or any other form of collective categorization. In addition to the empirical findings showing that collectivism is at odds with a major trend in citizens' values, a normative reason for this is that many of these collective belongings or identities are floating and that branding individuals (especially children and young people) into such collectives by administrative means can result in gross violations of their rights (Okin and Cohen 1999; Talbott 2005; Neier 2002). A second, and more important argument, is that there is no guarantee that the majority in groups like these will not oppress or exploit individuals that are put under their surveillance or, even worse, jurisdiction (Talbott 2005; Rawls 2005). In sum, arguments for increased equality should not be based on utilitarian group theory but instead theories about individual rights. This does not necessarily rule out what has been defined as multi-cultural policies. For example, for a Swedish speaking Finn, a Danish speaking German, or a French speaking Canadian, the right to learn and use ones native language in one's country need not be framed as a "group right" but can instead be framed as an individual right. Similarly, the right to have the availability of a set of cultural institutions should for a person belonging to a cultural/ethnic minority be seen as an individual right and not necessarily as a group right that may contribute to essentializing culture and ethnicity (cf. Kraus 2012).

\section{Reciprocity as the basic template for human interaction}

When striving for increased social solidarity, it is important to start from a correct understanding of "human nature", especially if you want your policies to have a lasting (sustainable) impact. 
Needless to say, ideas about the "basic human nature" have had a long history in the social sciences. The most compelling and empirically supported theory I have found is the work done in experimental research based on the idea of reciprocity (Fehr and Fischbacher 2005; Henrich et al. 2001; Gintis et al. 2005; Bicchieri 2006; cf. Ostrom 1998). To make a long story short, the idea of man as a "homo economicus" has simply been refuted by this type of research. The results from laboratory-, fieldwork-, and survey research speaking against man as a utilitymaximizing rational agent is by now overwhelming. Self-interest is for sure an important ingredient when people decide how to act, but it is far from as dominating as has been portrayed in neo-classic economics. Moreover, it would be impossible to create solidaristic or cooperative institutions of any kind (including democracy, the rule of law and respect for property rights) if individual utility-maximizing self-interest would be "the only game in town". The reason is that such individuals would sooner or later fall for the temptation to "free-ride" and if a majority do this, such institutions would never be established and if they existed (for some other reason) they would soon be destroyed (Miller 2000). If all agents act out of the template prescribed in neoclassic economic theory, they will sooner or later outsmart themselves into a suboptimal equilibrium. Also known as a "social trap" this is situation where all agents will be worse off because even if they know they would all gain from cooperation, lacking trust that the others will cooperate, they will themselves abstain from cooperation

However, this new experimental (and to some extent field) research does not present humans as benevolent altruists (Henrich and Henrich 2007; Bicchieri and Xiao 2009). True, there is altruistic behaviour, but it is usually restricted to very small circles of family and close friends. 
Or it is simply too rare and also too unpredictable for building sustainable systems for solidarity at a societal level. This lesson is important since it tells us that trying to mobilize political support for increased equality by referring only to peoples' altruistic motives is likely to fail (Svallfors 2007). What comes out from this research is instead that reciprocity is the basic human orientation. The central idea here is that people are not so much motivated "from the back" by utility-based calculations or culturally induced norms. Instead, human behaviour is to a large extent determined by forward looking strategic thinking in the sense that what agents do, depends on what they think the other agents are going to do (Gintis et al. 2005). Experimental studies show that people are willing to do "the right thing" but only if they can be convinced that most others are willing to do the same (Bicchieri and Xiao 2009; Strimling et al. 2013). Thus, the idea of reciprocity recasts fundamentally how we should understand and explain human behaviour. Instead of looking backwards to background variable for explaining what causes variation in utility-based interests or culturally induced norms, the important lesson from the research on reciprocity is to understand how people's forward looking perceptions about "other people" are constructed. Historical experiences and "collective memories" certainly play a role here, but research also shows that people update their perceptions based on new information (Boyd, Gintis, and Bowles 2010).

Regarding the prospect for solidarity, results from research show that most people are willing to engage in solidaristic cooperation for common goals even if they will not personally benefit from this materially (Levi 1998). However, for this to happen, three specific conditions have to be in place. First, people have to be convinced that the policy is morally justified (substantial justice). 
Secondly, people have to be convinced that most other agents can be trusted to also cooperate (solidaristic justice), that is that other agents are likely to abstain from "free-riding". Thirdly, people have to be convinced that the policy can be implemented in a fair and even-handed manner (procedural justice) (Levi 1991; Rothstein 1998). For the first issue, the work from the philosophers mentioned above will come in handy. The second requirement, which is as important for generating support for solidarity for policies for increased equality, has to be resolved by institutional design where knowledge from research in policy implementation and public administration in general are needed. For example: It is not difficult to argue that universal access to high quality health care and sickness insurance qualifies as a "primary good" in the above mentioned sense. However, if a majority cannot be convinced that a) most people will pay the increased taxes required for producing these goods, or that b) the good will not be delivered in a manner that is acceptable, fair and respectful, they are not likely to support this policy (Rothstein, Samanni, and Teorell 2012). If the health personnel are known to be corrupt, unprofessional or disrespectful, support for this policy will dwindle. The same goes for sickness insurance. People are likely to support insurance for people that are ill, but if perceptions of misuse or overuse (that is, "free-riding") become widespread, support will decline (Svallfors 2012; Rothstein 2011). In other words, solidarity is conditioned on the institutional design of the systems that are supposed to bring about the policies that will enhance equality. This has been formulated in the following words by John Rawls:

A just system must generate its own support. This means that it must be arranged so as to bring about in its members the corresponding sense of justice, an effective desire to act in 
accordance with its rules for reasons and justice. Thus, the requirements of stability and the criterion of discouraging desires that conflict with the principles of justice put further constraints on institutions. They must not only be just but framed so as to encourage the virtue of justice in those who take part in them. (Rawls 1971, 261)

The central idea in this quote is how Rawls specifies that for making a solidaristic system sustainable, we have to be aware of the existence of a "feed-back mechanism" between people's support for just principles and their perceptions of the quality of the institutions that are set up to implement these principles (Kumlin 2004). Recent empirical research strongly supports Rawls argument in the sense that individuals' perceptions of forms of unfairness (or inefficiency) in the public services influences political views about support for social solidarity. Using survey data for 29 European countries that includes questions about the fairness of public authorities (health sector and tax authorities) as well as questions about ideological leanings and policy preferences, Svallfors (2013) has shown the following: Citizens that have a preference for more economic equality but that lives in a country where they perceive that the quality of government institutions is low, will in the same survey indicate that they prefer lower taxes and less social spending. However, the same "ideological type" of respondent but who happens to live in a European country where he or she believes that the authorities that implement policies are basically just and fair, will answer that he or she is willing to pay higher taxes for more social spending. This result is supported in a study using aggregate data about welfare state spending and quality of government for Western liberal democracies (Rothstein, Samanni, and Teorell 2012) - the higher the quality of government the more countries will spend also when they 
control for variables that measures political mobilization and electoral success from left parties. To summarize my interpretation of these studies - citizens that live in a country where they perceive that corruption or other forms of unfairness in the public administration is common are likely to be less supportive of the idea that the state should take responsibility for policies for increased social justice even if they ideologically support the goals such policies have. The most likely reason is that they will believe that their solidarity will not be reciprocated.

Many scholars have generalized trust and reciprocity as if they are equivalents (Putnam 1993, 171ff; Ostrom 1990, 12). It should be obvious that they are not because reciprocity can have a very dark side. History and many contemporary events as well as experimental evidence show that "ordinary people" are willing to engage in the most horrible atrocities to other people (again, also if they do not personally benefit from their actions) if they are convinced that those "other people" would otherwise harm them (Browning 1992; Mann 2005). However, bad reciprocity also exists in less dramatic (and horrible) circumstances. Distrust in other agents or in the institutions may lead to a vicious circle that can break any system or policy set up to increase solidarity. Again, Rawls did clearly see this problem between institutional design and support for solidarity and justice (which has sadly been neglected by most of his followers in political philosophy):

For although men know that they share a common sense of justice and that each wants to adhere to existing arrangements, they may nevertheless lack full confidence in one another. They may suspect that some are not doing their part, and so they may be tempted not to do 
theirs. The general awareness of these temptations may eventually cause the scheme to break down. The suspicion that others are not honoring their duties and obligations is increased by the fact that, in absence of the authoritative interpretation and enforcement of the rules, it is particularly easy to find excuses for breaking them. (Rawls 1971, 240).

It is clear that Rawls pointed to the problem of reciprocity in the form of trust in others ("confidence") and that he argues that it is the existence of institutional arrangements that can handle "free-riding" and other forms of anti-solidaristic and opportunistic behaviour that are needed to avoid that systems based on principles of justice break down.

Thus, we arrive at the conclusion that regarding solidarity and justice, the basic nature of human behaviour - reciprocity - can go both ways. On the one hand, the idea of reciprocity stands against the cynicism about human nature that has been central to interest-based theories that has dominated most economic approaches in the social sciences (Ostrom 1998, 2000). On the other hand, reciprocity is also in conflict with a naïve idea about human nature as genuinely benevolent, which many equality-enhancing policies have been built on. Instead, reciprocity tells us that if we through the design of institutions can make people trust that most other agents in their society will behave in a trustworthy and solidaristic manner, they will do likewise. If not, they will defect, even if the outcome will be detrimental to their long-term interests.

That reciprocity can go in different directions is also what we see if we take just a simple look at most of the rankings of countries' performance that have now become abundant. The level of 
corruption, to take just one example, shows staggering differences between countries (Rothstein 2011). This particular "social bad" also serves as a good example of why reciprocity is a better starting point for understanding human behaviour than its rivals. If we relied on cultural explanations, we would have to say to our sisters and brothers in, for example, Nigeria that the extremely high level of corruption in their country is caused by their corrupt culture. Or if we started from interest based explanations, we would be unable to explain why the huge variation of corruption exists without relying on either genetic or cultural explanations. However, if we base our explanations on the idea of reciprocity, the explanation for the high level of corruption in, for example, Pakistan is that the institutions in place makes it reasonable for most people to believe that most other agents will be engaged in corrupt practices, and thus they have no reason not to engage in these practices themselves (Rothstein 2011). Simply put, it makes no sense to be the only honest policeman in a thoroughly corrupt police force. It is important to underline that, contrary to what is taken for granted in neo-classical economics, we have absolutely no reason to believe that societies (or any group of agents) are able to produce the type of institutions that they would prosper from. A quick look at available measures shows that a vast majority of the world's population live under either deeply or fairly corrupt public authorities (Holmberg and Rothstein 2012). This, it should be added, turns out to have devastating effects on their prosperity, social well-being and possibility to launch policies based on solidarity that will increase equality. 


\section{Reciprocity versus solidarity}

A central conclusion is thus that reciprocity, as the baseline for human agency, can go in two directions. One will result in more solidarity and cooperation for increased equality and thereby increased human well-being. The other one is exactly the opposite resulting in all sorts of bad outcomes such as high levels of corruption, discrimination, civil wars, massive exploitation and ethnic cleansing even in democratic societies (Mann 2005; cf. Lapuente and Rothstein 2014). Given what is known from the record of human history, it is not advisable to be naïve in these matters. We should never forget that even societies known for their high level of civilization have shown themselves to be capable of the worst imaginable forms of atrocities.

The most important thing we need to know is then what it is that makes reciprocity turn bad or good. Theory and research gives a reasonably clear answer to what determines the direction reciprocity will take society, namely the level of social or generalized interpersonal trust. Simply put, if most people in a society believe that most other people in that society can be trusted, they have good reasons to support policies that are based on solidarity and thereby will increase equality as it has been specified above. However, if they believe that most people should not be trusted, the outcome will be the opposite (Svallfors 2013; Rothstein 2011).

As with corruption, research on social trust (and the related concept of social capital) has increased tremendously since the mid-1990s. This is in part because empirical research shows 
that high levels of social trust at the individual level is connected to a number of important factors such as tolerance towards minorities, participation in public life, education, health, and subjective well-being. At the societal level, high trust societies have more extensive and generous social welfare systems (Rothstein and Uslaner 2005). However, how to understand a concept like social trust is not easy; obviously when asked in surveys, most people do not really know if most other people in their society can be trusted. One interpretation is that social trust is an expression of optimism about the future (Uslaner 2002). Another interpretation is that when people answer the survey question if they believe (or not) that most other people can be trusted, they are in fact answering another question, namely that they are making an evaluation of the moral standard of the society in which they live (Uslaner 2002; Delhey and Newton 2003). Both interpretations should be seen as answers to the central question for the way in which reciprocity will turn, namely what people believe about what other people will do if they try to engage in some collaborative effort with them. Again, the notion of reciprocity says that what people do depends on what they think other people will do, and this is likely to be determined by how they think about other people's trustworthiness, which of course can be seen as how they interpret the general moral standing of their society. For the case of creating a more equal society, the results are quite clear. Although not a perfect correlation, societies with more interpersonal trust have more political, economic and social equality, including gender equality (Rothstein 2005). It is important to note that I am here referring to what is known as generalized trust, that is, trust in people in general of whom there is no way to have anything that comes close to perfect information. This is different from particularistic trust which refers to trust in small groups of friends, clans or (social and professional) cliques. 


\section{Political institutions, social trust and social solidarity}

How then, can generalized trust be generated? Again, recent empirical research gives a reasonably clear answer to this question. A high level of generalized trust is caused by what has been called high quality government institutions, especially the institutions that implement public policies (Stolle 2003). The central basic norm for these institutions is impartiality. This implies that things like discrimination (whether based on ethnicity, gender, class, etc.), corruption (in its many forms), clientelism, nepotism and political favouritism are very rare or non-existent when public officials or professionals implement public policies. Social trust is thus not generated "from below", for example from civil society or voluntary associations, but "from above", by how people perceive the fairness and competence of government institutions (for an overview of this research see Rothstein 2013). In other words, it is trustworthy, uncorrupt, honest, impartial government institutions that exercise public power and implement policies in a fair manner that create generalized social trust. For example, using survey data from the World Value Study, Delhey and Newton concluded that "government, especially corruption free and democratic government, seems to set a structure in which individuals are able to act in a trustworthy manner and not suffer, and in which they can reasonably expect that most others will generally do the same" $(2004,28)$. Using survey data from 29 European countries, Bjørnskov (2004) concluded that a high level of social trust is strongly correlated with a low level of corruption. Another 
study, also based on comparative survey data, concludes that "the central contention ... is that political institutions that support norms of fairness, universality, and the division of power contribute to the formation of inter-personal trust" (Freitag and Buhlmann 2005).

Using scenario experiments in low trust/high corruption Romania and in high trust/low corruption Sweden, Rothstein and Eek (2009) found that persons in both these countries who experience corruption among public health care workers or the local police when travelling in an "unknown city in and unfamiliar country" do not only loose trust in these authorities but also in other people in general that "unknown" society. Another example is Svallfors (2013) study based on survey data from the European Social Survey carried out in 2008 that covers 29 countries in both western and Eastern Europe. This survey had questions related to corruption such as if people perceived that the tax authorities or the public health care gave "special advantages to certain people or deal with everyone equally?" The results are the following: Citizens that state in the survey that they have a preference for more economic equality but that lives in a country where they perceive that the quality of government institutions is low, will in the same survey indicate that they prefer lower taxes and less social spending. However, the same "ideological type" of respondent but who happens to live in a European country where he or she believes that the government authorities and guided by norms such as impartiality and fairness, will answer that he or she is willing to pay higher taxes for more social spending.

This result is supported in a study using aggregate data about welfare state spending and quality of government for Western liberal democracies (Rothstein, Samanni, and Teorell 2012) showing 
that the higher the quality of government, the more countries will spend on social services and benefits also when they control for variables that measures political mobilization and electoral success from left parties. To summarize - citizens that live in a country where they perceive that corruption or other forms of unfairness in the public administration is common are likely to be less supportive of the idea that the state should take responsibility for redistributive policies even if they ideologically support the goals such policies have. One likely reason is that they lack trust in other citizens to a) pay their taxes and b) not overuse or abuse the social insurances. Thus, designing institutions that implement public policy is to create (or destroy) social trust and thereby social solidarity. The reason for this effect is that when people make up their mind if most people in their society can be trusted, they make an inference from how they perceive the authorities. If the local policeman, schoolteacher, social insurance administrator, judge or doctor cannot be trusted (because they discriminate against people like you, or ask for bribes, or give preferential treatments to some groups, etc.), then it is reasonable to assume that neither should you trust "people in general" in your society. And vice versa, if they are known to be honest, impartial, competent and fair, then it is likely that this will spill over to "people in general". Moreover, if the public authorities are known to be engaged in the type of "bad" practices mentioned above, then many people will come to think that in order to get what they need in life (immunization to their children, building permits, employment in the public sector, etc.) most people will have to be engaged in these kinds of bad practices, and thus they should not be trusted (Rothstein 2011) The empirical evidence from both experimental and survey research gives a very strong support for this theory of how social trust is generated "from above" (Rothstein 2013). 
For social policy and many other policies that are intended to cater to increased equality in the above mentioned sense, this has a number of implications regarding institutional design. The most important is to strive for universal systems and avoid, as much as possible, systems that are directed to supporting "the poor" or "the vulnerable" (Rothstein 1998). Universal programs, like for example universal child allowances, universal pre-schools and schools, universal pensions, universal health care, are to be favoured instead of specific programs directed "the poor". The reasons for universalism are fivefold: First, universal systems entail a minimum of (if any) bureaucratic discretion. Thereby, not only corruption, but all forms of bureaucratic intrusions connected to needs-testing can be avoided. Secondly, since universal programs in principle cater to "all", they will include the middle class and thereby almost automatically secure a political majority and thereby make the program politically sustainable. Programs that are built solely on interest group mobilization will always be vulnerable to interest-based counter-mobilization. Sooner or later, a Thatcher or a Reagan will appear and these "types" will be able to construct a new alliance between the very rich and the middle class based on such interest mobilization. Thirdly, universal programs avoid the problem of stigmatization of specific groups and individual "stereotype-threat" that in experimental work has been shown to seriously hurt the ability of members of the "target group" to reach their potential (Steele 2010). Fourth, although they give benefits also to "rich" people, universal programs turn out to be very redistributive, more so than programs which "take from the rich and give to the poor". The reasons are that the benefits are usually nominal in money or costs of services, but taxes are either proportional to income or progressive (Korpi and Palme 1998; Rothstein 1998). Even when universal programs 
are income-related, such as for example many pension systems in more developed countries, there is usually a "cap" which makes them redistributive. Fifth, universal programs, especially when it comes to services like education or elderly care, will usually be of high quality since the need to keep the more well-to-do people "on board" will make it difficult for politicians to lower the quality of the services if they want to stay in power. In sum, universal programs have the capacity to "generate their own support" as stated by John Rawls above.

Admittedly, there are policies when universal institutions will not work. It is difficult to have a universal policy for active labour market policy since each unemployed person is different and will need different types of support in order to find a new job. The same goes for much of social assistance to dysfunctional families since each decision of whether or not to take a child into custody must be based on a professional judgement of the specificities of the particular case. In these areas, it is important to try as much as possible to use other means to ensure impartiality and fairness in how decisions are made in the implementation process. High quality training for professionals and civil servants, systems for accountability and control, possibilities to appeal, are but a few such possibilities.

\section{How the negative effect of diversity on social trust can be overcome?}

A central question is if this can work in societies with a high degree of ethnic/cultural/religious diversity? The initial positive view of the many good effects of social trust has been tampered by findings showing that societies with a high ethnic diversity tend to have lower social trust 
(Schaeffer 2014). Some economic studies claim that ethnic diversity, through its negative effects on social trust and social cohesion, explains why many poor countries fail to produce the amount of public goods necessary for social and economic development (Easterly and Levine 1997; Habyarimana et al. 2007). Putnam (2007) and Alesina and La Ferrara (1999) have also reported evidence for this causal link at the sub-national level for the U.S. Others have claimed that the increasing ethnic diversity in Western Europe will make redistribution to various welfare state programs more difficult (Alesina, Glaeser, and Sacerdote 2001; Eger 2010). This argument has not gone without criticism and several studies have pointed out that ethnic diversity does not necessarily or only under certain specific conditions destroy social trust (Banting and Kymlicka 2004; Uslaner 2012, Kumlin and Rothstein 2010; Gesthuizen, van der Meer, and Scheepers 2009). In a recent overview of this research, including no less than 480 empirical findings from 172 studies, Schaeffer $(2013,2014)$ convincingly shows that many studies about this controversial issue reach very different conclusions. This inconclusiveness is according to his analysis due to variation in research design such as which region of the world that is analyzed, which type of ethnic diversity that is scrutinized and also what type of measure is used for the dependent variable (production of public goods, collective action, civic engagement, social trust, trust related sentiments or support for redistribution). Schaeffer points out that while there is a slight overweight for the confirmatory studies, discipline matters a lot. Many more studies published in economics journals confirm the negative effect of ethnic diversity on social trust etc. than studies published in political science or sociology journals. However, he also shows that for the 58 studies that have generalized (social) trust as the dependent variable, there is close to a 
draw: 30 empirical results confirm and 28 confute the hypothesis that diversity has a negative effect on social trust (Schaeffer 2013, 12).

What is missing in most of these analyses is a variable of some significance, namely the state, or to use another terminology, the quality of government. First, as mentioned above a large number of studies have shown that generally, perceptions of living in a society with impartial, honest and largely un-corrupt government authorities has a positive impact on social trust. Secondly, three recent empirical studies have shown that if the quality of government factor is brought in, the negative effect of ethnic diversity on social trust either disappears or is strongly reduced. Using a survey from Sweden containing detailed questions about perceptions of how fairly respondents were treated by government authorities, Kumlin and Rothstein (2010) found that for (nonNordic) immigrants, perceptions of having been treated fairly by government authorities and public services had a significant positive effect on their social trust also when controlling for income, left-right orientation, being unemployed, membership in voluntary associations, age and gender.

Dinesen (2011) has carried out what is close to a natural experiment. He has studied what happens with immigrants from low trust countries when they immigrate to Western countries where the average level of social trust is higher. His results show that "immigrants who have migrated to countries with lower levels of corruption tend to have higher levels of trust than immigrants who have migrated to more corrupt countries" (Dinesen 2011, 56). In a study of immigrants to Denmark, which has the record in high social trust, Dinesen found that 
"perceptions of Danish institutions treating immigrants and native Danes evenhandedly have a strong impact on trust" and that this impact is particularly strong for immigrants (ibid.). With a special focus on young first and second generation immigrants, Dinesen found that "perceptions of institutional fairness at an early contribute to the general adaption of immigrants to the level of trust" of the native Danes $(2011,57)$.

The third study is built on a two surveys carried out in 2010 and 2013 by the Quality of Government Institute at University of Gothenburg (Charron and Rothstein 2014) The 2010 sample consisted of about 34.000 citizen interviews and the more recent survey sampled over 85,000 individuals making this the largest empirical investigation of this topic so far. The respondents have been sampled by regions in European countries, in total 212 so called NUTS 1 and NUTS 2 regions for 25 European countries ${ }^{3}$. These surveys have focused on citizen perceptions and experiences of the quality of their regional government institutions (the police, public health care and public schools) and included both perceptions regarding fairness and impartiality as well as questions about personal experiences of corruption (Charron, Lapuente, and Rothstein 2012).

These surveys show that the regional-level variation in social trust across Europe is striking, ranging from mere 8 percent social trusters in Východné Slovensko region in Slovakia to a stunning 80 percent in the Copenhagen region in Denmark. There are also high differences between regions in the same country. Not only as could be expected in Italy between the northern and the southern regions, but also in Germany with Saarland scoring 34 percent social 
trusters compared to Schleswig-Holstein where almost the double share of the respondents say that they believe that "most people can be trusted" (Charron and Rothstein 2014). Giving "one number" for variables such as social trust, ethnic diversity and the quality of government to whole countries in Europe can thus for many of these countries be highly misleading. This means that the advantage of using a regional sample does not only come from getting a larger number "societies" to compare but also that the quality of the measures are increased.

Combining this survey data with register data for the various regions in the European countries give an unique opportunity to analyze the effects of several competing explanations of social trust. The register data used for measuring ethnic diversity is the percentage of the population in the 212 regions that are born outside Europe. A simple bivariate analysis confirms the existence of a negative effect of ethnic diversity on social trust. However, this effect becomes negligible when the index for the quality government in the regions is entered. ${ }^{4}$ Furthermore, when controlling for QoG, the impact of activity and membership in voluntary associations for social trust also disappears while the importance of economic inequality remains significant. In other words, in those regions within European countries where people perceive that their public authorities are corrupt, dishonest and/or partial, this study confirms that ethnic diversity does have a negative effect on social trust. However, in regions where people perceive and experience that their regional authorities are reasonably impartial, honest and non-corrupt, the effect of ethnic diversity on social trust disappears (Charron and Rothstein 2014). 
The micro-level theory behind this could be understood in the following sense. Citizens facing increased diversity in a society with low quality of government may start thinking that people that are from a different ethnic group are getting away with overusing or misusing public and social services as well as avoiding taxes and therefore they should not be trusted. However, this type of suspicion is less likely in a society with high quality government which implies that not only the ethnic majority but also the newcomers have to play by the rules which give reason to believe that "most people in general can be trusted". As stated by the behavioral economists Fehr and Fishbacher about how to understand reciprocity: "If people believe that cheating on taxes, corruption and abuses of the welfare state are wide-spread, they themselves are more likely to cheat on taxes, take bribes or abuse welfare state institutions" $(2005,167)$. In sum, leaving the quality of the government out of the equation when studying the effect of ethnic diversity on social trust and solidarity turns out to be a mistake. As shown by Larsen (2013), although Denmark and Sweden have received a large amount of immigrants from countries outside Europe since the early 1980s, social trust as measured by the World Value surveys have increased (from already high levels) under the same period.

\section{Conclusions}

The result from using the constructive theory approach for the problem of how to increase social solidarity can be summarized in one sentence. High quality of government institutions will increase the level of social trust, which will make reciprocity turn into solidarity despite the degree of ethnic diversity, which in turn will increase the possibility for creating sustainable 
social solidarity. One counterintuitive result from the studies discussed is perhaps that a high level of QoG ameliorates the negative effects of ethnic diversity and immigration on social trust, a problem that has been reported in a large number of studies and which has become known as "the new liberal dilemma". Another counterintuitive result from this analysis is perhaps that in order to support the "needy", "poor", or "discriminated" one should avoid policies that are directed specifically at these groups. Because of their lack of interest in the implementation issues and also research about public opinion about support for policies for social justice, many well-known political philosophers have failed to see this. To the list mentioned above, Brian Barry and Amy Gutman can be added since both have argued against universal policies because they wrongly believed that such policies will not help poor people (see Rothstein 1998, 148f). The issues about how people perceive the fairness, impartiality and justice in the implementation of policies for social justice have been greatly underestimated. When striving for increased social solidarity, universal policies are much more likely to be implemented in ways that are considered fair, impartial and just than are policies that are targeted to "the poor". Moreover, it is countries that "taxes all" and "supports all" through universal programs that succeeds in redistribution while countries that "taxes the rich to give to the poor" fail to do so. The logic is quite simple, services and benefits intended "for the poor" are likely to be "poor" services and benefits thereby increasing stigmatization of the group one wants to support. If the "middle class" is left out of the system for social solidarity, there will neither be an electoral majority for policies for social solidarity nor enough taxes to pay for such policies. To paraphrase Rawls $(1971,261)$, such a system for social justice will be unable to "generate its own support". 


\section{References}

Ackerman, Bruce C. 1980. Social Justice and the Liberal State. New Haven: Yale University Press.

Alesina, Alberto, Edward L. Glaeser, and B. Sacerdote. 2001. "Why Doesn't the United States Have a European-Style Welfare State?” Brookings Papers on Economic Activity (2): 187-277.

Alestalo, Matti, Sven E. O. Hort, and Stein Kuhnle. 2009. “The Nordic Model: Conditions, Origins, Outcomes, Lessons.” Berlin: Hertie School of Governance.

Anderson, Elizabeth S. 1999. "What Is the Point of Equality?" Ethics 109 (2): 287-337.

Anttonen, Anneli, Liisa Häikiö, and Stefánsson Kolbeinn. 2012. Welfare State, Universalism and Diversity. Cheltenham: Edward Elgar.

Arneson, Richard J. 1990. "Libealism, Distributive Justice, and Equal Opportunity for Welfare." Philosophy and Public Affairs 19: 151-71.

Banting, Keith G. 2010. “Is There a Progressive's Dilemma in Canada? Immigration, Multiculturalism and the Welfare State.” Canadian Journal of Political Science/Revue Canadienne de Science Politique 43 (4): 797-820. 
Banting, Keith, and Will Kymlikca. 2004. "Do Multiculturalism Policies Erode the Welfare State.” Kingston, ON: School of Policy Studies, Queens University.

Bay, Ann-Helén, and Axel West Pedersen. 2006. "The Limits of Social Solidarity: Basic Income, Immigration and the Legitimacy of the Universal Welfare State.” Acta Sociologica 49 (4): 41029.

Béland, Daniel. 2005. Social Security: History and Politics from the New Deal to the Privatization Debate. Lawrence: University Press of Kansas.

Bicchieri, Christina. 2006. The Grammar of Society: The Nature and Dynamics of Social Norms. New York: Cambridge University Press.

Bicchieri, Chistina, and Erte Xiao. 2009. "Do the Right Thing: But Only if Others Do So." Journal of Behavioral Decision Making 22 (2): 191-208.

Birnbaum, Simon. 2012. Basic Income Reconsidered: Social Justice, Liberalism, and the Demands of Equality. $1^{\text {st }}$ ed. New York: Palgrave Macmillan.

Bohara, Alok K., Neil J. Mitchell, Mani Nepal, and Nejem Raheem. 2008. "Human Rights Violations, Corruption, and the Policy of Repression." Policy Studies Journal 36 (1): 1-18. 
Boyd, Robert, Herbert Gintis, and Samuel Bowles. 2010. "Coordinated Punishment of Defectors Sustains Cooperation and Can Proliferate When Rare.” Science 328 (5978): 617-20.

Browning, Christopher R. 1992. Ordinary Men: Reserve Police Battalion 101 and the Final Solution in Poland. New York: HarperCollins.

Cavala, Bill, and Aaron Wildavsky. 1970. "The Political Feasability of Income by Right." Public Policy 18: 321-54.

Charron, Nicholas, Victor Lapuente, and Bo Rothstein. 2012. Quality of Government and Corruption from a European Perspective. Cheltenham: Edward Elgar.

Charron, Nicholas, and Bo Rothstein. 2014. "Regions of Trust and Distrust. Explaining Patterns of Social Trust at the Sub-National Level in Europe.” Paper presented at the XIII Internal Conference of the Quality of Government Institute, Krakow, January 28-30.

De Wispelaere, Jürgen, and Lindsay Stirton. 2011. "The Administrative Efficiency of Basic Income." Policy and Politics 39 (1): 115-32.

Delhey, Jan, and Kenneth Newton. 2003. "Who Trusts? The Origines of Social Trust in Seven Societies.” European Societies 5 (2): 93-137. 
Dinesen, Peter Thisted. 2011. "When in Rome, Do as the Romans Do? An Analysis of the Acculturation of Generalized Trust of Non-Western Immigrants in Western Europe.” PhD diss., Aarhus University, Aarhus.

Donnelly, Jack. 2003. Universal Human Rights in Theory and Practice. $2^{\text {nd }}$ ed. Ithaca: Cornell University Press.

Dryzek, John S., Bonnie Honig, and Anne Phillips. 2006. “Introduction.” In The Oxford Handbook of Political Theory, edited by J. S. Dryzek, B. Honig, and A. Phillips. Oxford: Oxford University Press.

Easterly, William, and Ross Levine. 1997. “Africa's Growth Tragedy: Policies and Ethnic Divisions." The Quarterly Journal of Economics 112 (4): 1203-50.

Eger, Maureen A. 2010. "Even in Sweden: The Effect of Immigration on Support for Welfare State Spending.” European Sociological Review 26 (2): 203-17. doi:10.1093/esr/jcp017.

Erman, Eva, and Niklas Möller. 2015. "Political Legitimacy in the Real Normative World: The Priority of Morality and the Autonomy of the Political." British Journal of Political Science 45 (1): $215-33$. 
Erman, Eva, and Niklas Möller. 2013. "Three Failed Charges Against Ideal Theory.” Social Theory and Practice 39 (1): 40-60.

Estlund, David. 2008. Democratic Authority. Princeton: Princeton University Press.

Fehr, Ernst, and Urs Fischbacher. 2005. "The Economics of Strong Reciprocity.” In Moral Sentiments and Material Interests. The Foundations for Cooperation in Economic Life, edited by H. Gintis, S. Bowles, R. Boyd, and E. Fehr. Cambridge, MA: The MIT Press.

Freitag, Markus, and Marcus Buhlmann. 2005. "Political Institutions and the Formation of Social Trust. An International Comparison.” Politische Vierteljahresschrift 46 (4): 575-86

Gesthuizen, Maurice, Tom van der Meer, and Peer Scheepers. 2009. "Ethnic Diversity and Social Capital in Europe: Tests of Putnam's Thesis in European Countries." Scandinavian Political Studies 32 (2): 121-42.

Gintis, Herbert, Samuel Bowles, Robert Boyd, and Ernst Fehr, eds. 2005. Moral Sentiments and Material Interests. The Foundations for Cooperation in Economic Life. Cambridge, MA: The MIT Press. 
Habyarimana, James, Macartan Humphreys, David N. Posner, and Jeremy M. Weinstein. 2007. “Why Does Ethnic Diversity Undermine Public Goods Provision?” American Political Science Review 101 (4): 709-25.

Hall, Peter A., and Michèle Lamont, eds. 2009. Successful Societies: How Institutions and Culture Affect Health. New York: Cambridge University Press.

Halleröd, Björn, Bo Rothstein, Adel Daoud, and Shailen Nandy. 2013. "Bad Governance and Poor Children: A Comparative Analysis of Government Efficiency and Severe Child Deprivation in 68 Low- and Middle-income Countries.” World Development 48: 19-31.

Henrich, J., R. Boyd, S. Bowles, C. Camerer, E. Fehr, H. Gintis, and R McElreath. 2001. “In Search of Homo Economicus: Behavioral Experiments in 15 Small-Scale Societies." American Economic Review 91 (2): 73-78.

Henrich, Natalie, and Joseph Patrick Henrich. 2007. Why humans cooperate : a cultural and evolutionary explanation. Oxford ; New York: Oxford University Press.

Holmberg, Sören, and Bo Rothstein, eds. 2012. Good Government: The Relevance of Political Science. Cheltenham: Edward Elgar. 
Jefferson, Philip N., ed. 2012. The Oxford Handbook of the Economics of Poverty. Oxford: Oxford University Press.

Klein, Rudolf. 2010. The New Politics of the National Health Service (6th ed). $3^{\text {rd }}$ ed. London: Longman.

Korpi, Walter, and Joakim Palme. 1998. "The Paradox of Redistribution and Strategies of Equality: Welfare State Institutions, Inequality, and Poverty in the Western Countries.” American Sociological Review 63 (5): 661-87.

Kraus, Peter A. 2012. "The Politics of Complex Diversity: A European Perspective." Ethnicities $12(1): 3-25$.

Kuhnle, Stein, and Sven E. O. Hort. 2004. "The Developmental Welfare State in Scandinavia: Lessons for the Developing World." Geneva: United Nations Research Institute for Social Development.

Kumlin, Staffan. 2004. The Personal and the Political: How Personal Welfare State Experiences Affect Political Trust and Ideology. New York: Palgrave/Macmillan.

Kumlin, Staffan, and Bo Rothstein. 2010. "Questioning the New Liberal Dilemma: Immigrants, Social Networks and Institutional Fairness." Comparative Politics 41 (1): 63-87. 
Lapuente, Victor, and Bo Rothstein. 2014. "Civil War Spain Versus Swedish Harmony: The Quality of Government Factor.” Comparative Political Studies 47 (10): 1416-41. doi:10.1177/0010414013512598.

Larsen, Christian Albrekt. 2007. "How Welfare Regimes Generate and Erode Social Capital The Impact of Underclass Phenomena.” Comparative Politics 40 (1): 83-110.

Larsen, Christian Albrekt. 2008. "The Institutional Logic of Welfare State Attitudes.” Comparative Political Studies 41 (2): 145-68.

Larsen, Christian Albrekt. 2013. The Rise and Fall of Social Cohesion. The Construction and Deconstruction of Social Trust in the US, UK, Sweden and Denmark. Oxford: Oxford University Press.

Levi, Margaret. 1991. “Are There Limits to Rationality.” Achives Européennes de Sociologie 32 (1): $130-41$.

Levi, Margaret. 1998. Consent, Dissent, and Patriotism. New York: Cambridge University Press.

Lundquist, Lennart. 1988. Byråkratisk etik. Lund: Studentlitteratur. 
Mann, Michael. 2005. The Dark Side of Democracy: Explaining Ethnic Cleansing. New York: Cambridge University Press.

Miller, Gary. 2000. "Rational Choice and Dysfunctional Institutions." Governance: An International Journal of Policy and Administration 13 (4): 535-47.

Neier, Aryeh. 2002. Taking Liberities: Four Decades in the Struggle for Rights. New York: Public Affairs.

Norris, Pippa. 2012. Democratic Governance and Human Security: The Impact of Regimes on Prosperity, Welfare and Peace. New York: Cambridge University Press.

Nussbaum, Martha C. 2001. “The Enduring Significance of John Rawls.” The Chronicle of Higher Education: The Chronicle Review, July 20.

OECD. 2011. "The Causes of Growing Inequality in OECD Countries." Paris: OECD Publishing.

Offe, Claus. 2004. "Wasteful Welfare Transaction. Why Basic Income is Fundamental.” In Promoting Income Security as a Right :Europe and North America, edited by S. Guy. London: Wimbledon Publishing. 
Okin, Susan Moller, and Joshua Cohen. 1999. Is Multiculturalism Bad for Women? Princeton, NJ: Princeton University Press.

Ostrom, Elinor. 1998. “A Behavioral Approach to the Rational Choice Theory of Collective Action.” American Political Science Reveiw 92 (1): 1-23.

Ostrom, Elinor. 2000. “Crowding out Citizenship.” Scandinavian Political Studies 23 (1): 3-16.

Pontusson, Jonas. 2005. Inequality and Prosperity: Social Europe vs. Liberal America. Ithaca, NY: Cornell University Press.

Pribble, Jennifer E. 2013. Welfare and Party Politics in Latin America. New York: Cambridge University Press.

Radcliff, Benjamin. 2013. The Political Economy of Human Happiness. New York: Cambridge University Press.

Rawlings, Laura B, and Gloria M. Rubio. 2005. "Evaluating the Impact of Conditional Cash Transfer Programs.” World Bank Research Observer 20 (1): 29-55.

Rawls, John. 1971. A Theory of Justice. Oxford: Oxford University Press. 
Rawls, John. 2005. Political Liberalism (expanded edition). New York: Columbia University Press.

Risse, Mathias. 2002. "What Equality of Opportunity Could Not Be.” Ethics 112: 720-47.

Roemer, John E. 1995. “Equality and Responsibility.” Boston Review. http://new.bostonreview.net/BR20.2/roemer.html.

Roemer, John E. 1996. Theories of Distributive Justice. Cambridge: Harvard University Press.

Roemer, John E. 1998. Equality of Opportunity. Cambridge, MA: Harvard University Press.

Roemer, John E. 2009. “The Prospects for Achieving Equality in Market Economies.” In The Oxford Handbook of Economic Inequality, edited by W. Salverda, B. Nolan, and T. M. Smeeding. Oxford: Oxford University Press.

Rothstein, Bo. 1998. Just Institutions Matter: The Moral and Political Logic of the Universal Welfare State. Cambridge: Cambridge University Press.

Rothstein, Bo. 2005. Social Traps and the Problem of Trust. Cambridge: Cambridge University Press. 
Rothstein, Bo. 2010. “Happiness and the Welfare State.” Social Research 77 (2): 441-68.

Rothstein, Bo. 2011. The Quality of Government: Corruption, Social Trust and Inequality in a Comparative Perspective. Chicago: The University of Chicago Press.

Rothstein, Bo. 2013 "Corruption and Social Trust: Why the Fish Roots from the Head Down." Social Research 80 (4): 1009-32.

Rothstein, Bo, and Daniel Eek. 2009. "Political Corruption and Social Trust - An Experimental Approach." Rationality and Society 21 (1): 81-112.

Rothstein, Bo, Marcus Samanni, and Jan Teorell. 2012. "Explaining the Welfare State: Power Resources vs. the Quality of Government.” European Political Science Review 4 (1): 1-28.

Rothstein, Bo, and Eric M. Uslaner. 2005. "All for All. Equality, Corruption and Social Trust.” World Politics 58 (3): 41-73.

Schaeffer, Merlin. 2013. "Ethnic Diversity, Public Goods Provision and Social Cohesion. Lessons from an Inconclusive Literature.” Discussion Paper No. SP VI 2013-103, WZB Social Research Center, Berlin. 
Schaeffer, Merlin. 2014. Ethnic Diversity and Social Cohesion. Immigration, Ethnic

Fractionalization and Potentials for Civic Action. Farnham, Surrey: Ashgate.

Scharpf, Fritz W. 2000. "Basic Income in Social Europe.” In Basic Income on the Agenda, edited by R. v. d. Veen and L. Groot. Amsterdam: Amsterdam University Press.

Schemmel, Christian. 2007. "On the Usefulness of Luck Egalitarian Arguments for Global Justice." Global Justice: Theory, Rethoric, Practice 1: 55-67.

Sen, Amartya. 1979. “Equality of what?” Stanford, CA: The Tanner Lecture of Human Values.

Sen, Amartya. 2010. The Idea of Justice. Johanneshov: TPB.

Solevid, Maria. 2009. Voices from the Welfare State: Dissatisfaction and Political Action in Sweden. Gothenburg: Department of Political Science, University of Gothenburg.

Sugiyama, Nastascha Borges, and Wendy Hunter. 2013. "Whither Clientelism? Good Governance and Brazil's Bolsa Familia Program." Comparative Politics 46 (1): $43-63$.

Steele, Claude. 2010. Whistling Vivaldi: And other Clues to How Stereotypes Affect Us. New York: W. W. Norton \& Company. 
Strimling, Pontus, Staffan I. Lindberg, Micael Ehn, Kimmo Eriksson, and Bo Rothstein. 2013. "Can Efficient Institutions Induce Cooperation Among Low Trust Agents? An Experimental Approach?" Working Paper No. 2013:7, The Quality of Government Institute, University of Gothenburg, Gothenburg.

Stolle, Dietlind. 2003. “The Sources of Social Capital.” In Generating Social Capital: Civil Society and Institutions in a Comparative Perspective, edited by M. Hooghe and D. Stolle. New York: Palgrave/Macmillan.

Svallfors, Stefan, ed. 2007. The Political Sociology of the Welfare State : Institutions, Social Cleavages, and Orientations. Stanford, CA: Stanford University Press.

Svallfors, Stefan. 2012. "Government Quality, Egalitarianism, and Attitudes to Taxes and Social Spending: A European Comparison." European Political Science Review (online preview).

Talbott, William J. 2005. Which Rights Should be Universal? New York: Oxford University Press.

Tsebelis, George. 1990. Nested Games: Rational Choice in a Comparative Perspective. New York: Cambridge University Press.

Uslaner, Eric M. 2002. The Moral Foundation of Trust. New York: Cambridge University Press. 
Uslaner, Eric M. 2012. Segregation and Mistrust: Diversity, Isolation, and Social Cohesion. Cambridge: Cambridge University Press.

Uslaner, Eric M., and Bo Rothstein. 2012. "Mass Education, Statebuilding and Equality: Searching for the Roots of Corruption." QoG Working Paper No. 2012:5, The Quality of Government Institute, University of Gothenburg, Gothenburg, Sweden.

Van Parijs, Philippe, ed. 1992. Arguing for Basic Income. London: Verso.

Veen, Robert van der, and Loek Groot. 2000. Basic Income on the Agenda: Policy Objectives and Political Chances. Amsterdam: Amsterdam University Press.

Welzel, Christian. 2010. "How Selfish Are Self-Expression Values? A Civicness Test.” Journal of Cross-Cultural Psychology 41 (2): 152-74.

Wilkinson, Richard G., and Kate Pickett. 2009. The Spirit Level: Why More Equal Societies Almost Always Bo Better. London: Allen Lane.

Wolff, Jonathan. 2011. Ethics and Public Policy: A Philosophical Inquiry. Milton Park, Abingdon, Oxon; New York: Routledge. 


\section{Notes}

${ }^{1}$ Increased equality in the work life and in the family is for sure also important, but for reasons of space, I leave this out.

${ }^{2}$ Data can be obtained from the author.

${ }^{3}$ NUTS refer to 'Nomenclature of territorial units for statistics', and are EU statistical regions, for more information, see:

http://epp.eurostat.ec.europa.eu/portal/page/portal/nuts_nomenclature/introduction.

${ }^{4}$ In order to avoid the problem of simultaneity, the measure of social trust is taken from the 2013 survey and the measure of quality of government (QoG) for the regions is from the 2010 survey which implies that data about social trust and the data about experiences and perceptions of QoG are not from the same people in the same survey. 